\title{
The use of $90 \%$ Aloe vera freeze drying as the modulator of collagen density in extraction socket of incicivus Cavia cobaya
}

Ester Arijani and Christian Khoswanto Department of Oral Biology

Faculty of Dentistry, Airlangga University

Surabaya - Indonesia

\begin{abstract}
Wound healing is basically a complex process in which cellular and matrix act in concern to re-establish the integrity of injury tissues. This process can be simplified to be healing process consisted of haemostatic, inflammation, cell proliferation and tissue remodeling. The aimed of this research was to know the influence of freeze drying $90 \%$ Aloe vera application as mandible collagen density modulator in extraction socket of incisive Cavia cobaya. This research was done using Post Test Only Control Groups Design and Cavia cobaya as the sample. Six samples of each control group and 90\% Aloe vera group applied to test each collagen density for three days and seven days. Then, the data was analyzed statistically using Mann Whitney with 5\% significance rate. The result of the study indicates that administering $90 \%$ Aloe vera can accelerate the growth of collagen density in healing process of extraction socket. The conclusion is $90 \%$ Aloe vera can modulate the density of collageneous fiber in socket of extraction incicivus tooth wound of Cavia cobaya.
\end{abstract}

Key words: collagen, Aloe vera

Correspondence: Ester Arijani, c/o: Departemen Biologi Oral, Fakultas Kedokteran Gigi Universitas Airlangga. Jln. Mayjend. Prof. Dr. Moestopo No. 47 Surabaya 60132, Indonesia. E-mail: christiankhoswanto@ hotmail.com

\section{INTRODUCTION}

Anti inflammation medicine has been widely available in the market, however, the price is still relatively expensive. This matter really stimulates researchers to use traditional herb as alternative medicine in which the material is easily obtained and the price is affordable. One of traditional plants which is widely used is Aloe vera known as lidah buaya.

Based on the result of reported study that Aloe vera can function as anti inflammation, antibacterial, antivirus, antifungi, antiallergy, increasing immunity, accelerating wound healing process by increasing cell regeneration and lowering blood sugar level., ${ }^{1,2}$

Aloe vera has been widely used in dentistry due to its multiple benefits. The use of Aloe vera as a tooth paste helps recover mandible inflammation and lower coloring due to cigarette smoking. ${ }^{3}$ In addition, product which consists of Aloe vera can be used for gingivitis treatment, pain due to denture use and other oral disturbances. Aloe vera can also directly be used for mandible inflammation treatment by giving fresh resin to mouth sore, supporting wound healing and functioning as pain relief. ${ }^{4}$

Observation result on wound of baby mice was given Aloe vera resin would close twice faster than the wound of baby mice without being given medication. Microscopic observation on tissue of wound area showed wound closing and union of skin tissue faster in baby mice given Aloe vera resin. Regeneration of epithelial cells will occur faster and also the formation of new blood vessel as well as the number of phagocyte cell is higher. Aloe vera consists of glucomannan and giberrelins which function to stimulate fibroblast to proliferate faster in wound area and to accelerate wound healing with epithelial cell proliferation as well as to prevent infection which could inhibit wound healing. 5

Wound healing basically is complicated process in which cellular and matrix component functions to regain the integrity of damage tissue, this process can be simplified to be healing process which consists of homeostasis, inflammation, cell proliferation and tissue remodeling. During the process, some protein structure would develop especially for rigidity elasticity and strength, which depend on the adjacent environment and functional need that is collagen. Collagen can be found in all region of the body such as dermist, plain muscle, bone, cartilage and basal membrane. Collagen is protein which is mostly found in human body in which $30 \%$ of total weight collagen consists of $33.5 \%$ glicine amino acid, $12 \%$ proline, $10 \%$ proline hydroxide and other amino acids.

The purpose of this study was to know the effect of freeze drying $90 \%$ Aloe vera application as mandible collagen density modulator in of incicivus Cavia cobaya.

\section{MATERIALS AND METHODS}

This research was an experimental laboratory study using Post-Test Only Control Groups Design. The tools and materials were forceps, special elevator, scissor, syringe 
$2.5 \mathrm{cc}$, pinset, cover glass, object glass, microtom, heater, balance, sterile aquadest, $90 \%$ Aloe vera, either, absolute alcohol, 70\%, 80\%, 90\%, 95\%, 99\% alcohol, formalin solution, paraffin, xylol, MA staining, nitrate acid.

General anesthetic was done on Cavia cobaya which was fulfilled the requirement using $10 \%$ either in special box. Right lower incicivus tooth was cleaned from the food debris by water spraying then it was dried. The incicivus tooth was carefully extracted using needle holder and elevator (all the tools had been sterilized before being used) done in the same direction to prevent the tooth root from fracture, and the tooth was perfectly extracted, then the socket was irrigated by sterile aquadest. Aloe vera was given orally by inserting into the syringe, dropped into the socket until completely filled and put it into the wound in post extracted region and sutured.

The execution was done using $10 \%$ either in lethal dosis on day 3 and 7. The mandible was taken by releasing from the angulus mandible and removed. The specimen was staining using Mallory Azan to see the collagen fibers in light microscopy using 400× magnificent. The data from collagen density, were tabulated and statistical analysis was done using Mann Whitney test with 5\% significance rate.

\section{RESULT}

On the study of 24 samples of Cavia cobaya were classified into control groups and Aloe vera groups which applied $90 \%$ Aloe vera gel in the socket which was used for incicivus tooth extraction by making histological preparation taken on day 3 and day 7 .

Table 1 shows the result from histological preparation based on collagen appearance from socket incisivus Cavia cobaya.

Table 2 shows the Mean and standard deviation of collageneous fiber density. The table shows the increase of collageneous fiber density on day 3 and 7 either in control and $90 \%$ Aloe vera groups.
Table 2. Mean and standard deviation of collageneous fiber density

\begin{tabular}{lccc}
\hline \multirow{2}{*}{ Time } & \multirow{2}{*}{ Number } & Control & $90 \%$ Aloe vera \\
\cline { 3 - 4 } & & $\overline{\mathrm{X}} \pm \mathrm{SD}$ & $\overline{\mathrm{X}} \pm \mathrm{SD}$ \\
\hline Day 3 & 6 & $0,83 \pm 0,41$ & $1,33 \pm 0,51$ \\
Day 7 & 6 & $1,50 \pm 0,51$ & $2,66 \pm 0,51$ \\
\hline
\end{tabular}

Table 3. The significant difference of collageneous fiber density

\begin{tabular}{cc}
\hline Time & Assym. Sig. (2-tailed) \\
\hline Day 3 & 0.092 \\
Day 7 & 0.011 \\
\hline
\end{tabular}

Table 3 shows the number of collageneous fiber on day 3 did not show significant difference from control group $\mathrm{p}=0.092$ while day 7 showed significant difference in the wound given $90 \%$ Aloe vera from the wound without $90 \%$ Aloe vera (control group) $\mathrm{p}=0.01$

\section{DISCUSSION}

Collagen is a protein which is most frequently found in human body, covering $30 \%$ of its drying weight. The main amino acid that composed collagen are glicine, proline and hydroxilicine. Collageneous fiber is long fine structure with diameter varies between $20-90 \mathrm{~nm}{ }^{6}$

The result of histological preparation showed the increase number of collageneous fiber on day 3 and day 7 either in control groups or tested groups. Day 3 and day 7 were selected to be the indications based on the consideration that on day 3 collageneous fiber was formed and fibroblast proliferation occurred, while on day 7 collagen had been accumulated. ${ }^{7}$ The comparison of collageneous fiber score number showed higher of

Table 1. The data of collagen appearance on day 3 and 7

\begin{tabular}{|c|c|c|c|c|}
\hline \multirow{3}{*}{ Day } & \multicolumn{4}{|c|}{ Group } \\
\hline & \multicolumn{2}{|c|}{ Control Group } & \multicolumn{2}{|c|}{ Aloe vera Group } \\
\hline & Group & Score & Group & Score \\
\hline \multirow[t]{6}{*}{ Day 3} & Control 3.1 & 1 & Aloe vera 3.1 & 1 \\
\hline & Control 3.2 & 1 & Aloe vera 3.2 & 1 \\
\hline & Control 3.3 & 1 & Aloe vera 3.3 & 2 \\
\hline & Control 3.4 & 1 & Aloe vera 3.4 & 1 \\
\hline & Control 3.5 & 1 & Aloe vera 3.5 & 1 \\
\hline & Control 3.6 & 1 & Aloe vera 3.6 & 2 \\
\hline \multirow[t]{6}{*}{ Day 7} & Control 7.1 & 1 & Aloe vera 7.1 & 2 \\
\hline & Control 7.2 & 2 & Aloe vera 7.2 & 3 \\
\hline & Control 7.3 & 2 & Aloe vera 7.3 & 3 \\
\hline & Control 7.4 & 1 & Aloe vera 7.4 & 3 \\
\hline & Control 7.5 & 1 & Aloe vera 7.5 & 3 \\
\hline & Control 7.6 & 2 & Aloe vera 7.6 & 3 \\
\hline
\end{tabular}


collageneous fiber in control groups than tested groups either on day 3 or day 7 (Table 2).

The result of data analysis showed significant difference between control group and treatment group. The result suggested no significant difference was found between control group and Aloe vera group in which both groups on day 3 , it is possible due to wound healing process on day 3 the formation of new collageneous fiber just started so the effect given by $90 \%$ Aloe vera tested group to stimulate collageneous fiber formation had not occurred. While between control group and tested group in which each group on day 7 showed significant difference due to the effect of $90 \%$ Aloe vera given to tested group had already functioned.

Significant difference in the number of collageneous fiber in control group and tested group was due to Aloe vera content which functioned to stimulate wound healing process. Aloe vera functions to stimulate the growth of new fibroblast cell and to accelerate wound healing due to the substance content such as glucomannan which is polysaccharide complex mostly consisting of sugar mannose in which could stimulate fibroblast to proliferate faster in wound region. Gibberelins is growth hormone which could stimulate fibroblast proliferation and accelerate protein sinthesis. ${ }^{6}$

Aloe vera consist of vitamin $\mathrm{A}, \mathrm{B}, \mathrm{B}_{1}, \mathrm{~B}_{2}, \mathrm{~B}_{3}, \mathrm{~B}_{6}$, $\mathrm{C}, \mathrm{D}, \mathrm{E}$ niachinamida, cholin, folate acid which are important for growth and improvement of damaged tissue. ${ }^{8}$ A study suggests that vitamin given orally could increase the formation of collageneous fiber. ${ }^{9}$ Amylase, catalase, celluse, oxidase, lipase, protease enzyme regulate chemical process in the human body and accelerate wound healing and regeneration process. Aloe emodin in Aloe vera is useful to support recovery and improvement of damaged tissue and also relieve the pain. Antraquinones has the effect of anti inflammation, analgesic and anti microbe. Saponine has the effect of anti septic, anti microbe, anti fungi and anti virus. Amino acid in Aloe vera is important for growth and tissue proliferation. .,10,11 $^{-1}$

Antimicrobial and anti septic substance in Aloe vera are useful to prevent infection which is one of the most influence local factors in wound healing process. Healing varies according to the turnover times of the tissue. ${ }^{12}$ The occurrence of infection can inhibit the wound healing.

In addition to various useful contents for medical treatment, Aloe vera also has harmful and dangerous content for health. The yellow resin containing Antraquinone is a laxative irritant producing that can harm enzymatic system in gastric wall and contribute toxic effect in human body and that was it is not applied on this study. Aloe vera had been peeled up and washed until it was free from yellow resin before the process and freeze drying method were done. The conclusion is $90 \%$ Aloe vera can modulate the density of collageneous fiber in socket of extraction incicivus tooth wound of Cavia cobaya.

\section{REFERENCES}

1. Wolfe B. The handbook of Aloe vera. New Mexico: Albuquerque; 2001. p. 116-7.

2. Furnawanthi I. Khasiat dan manfaat lidah buaya. Bogor. 2002. p. 25-30.

3. Trelia B. Daya anti bakteri pada beberapa konsentrasi dan kadar hambat tumbuh minimal Aloe vera. Dentika Dental Journal 2002; 7(1): 58-66.

4. Hembing HM. Tanaman berkhasiat obat di Indonesia. Jakarta: Pustaka Kartini; 1992. p. 622-7, 1070 .

5. Davis R. Biological activity of Aloe vera. Available at: http://www. aloevera and polysacharadis.com. Accessed April 2006.

6. Junqueira LC, Carneiro J, Kelley RO. Basic histology. $9^{\text {th }}$ ed. Appleton and Lange. 2006. p. 91-120.

7. Vinay K, et al. Robbins pathologic basic of disease. $6^{\text {th }}$ ed. Toronto: WB Saunders Company; 1999. p. 98-9, 102-11.

8. Santoso HB. Lidah buaya juga untuk kanker. Rubrik Media Medis Senior; 2000. p. 28.

9. Kathleen A. Effect of retinoic acid and airspace development and lung collagen in hyperoxia-exposed newborn rats. Paediatric Research 2000; 48:434-44.

10. Sullatia GG, dkk. Farmakologi dan terapi. Edisi ke-4. Jakarta: Bagian Farmakologi Fakultas Kedokteran Universitas Indonesia; 2001. p. $220-7$.

11. Nanci A. Oral histology development structure and function. $6^{\text {th }}$ ed. St Louis: Mosby; 2003. p. 410.

12. Bath MB, Fehrenbach MJ. Dental embryology, histology and Anatomy. $2^{\text {nd }}$ ed. Missouri: Elsevier Saunders; 2006. p. 149. 